\title{
Rescue of corpus callosum agenesis in two ciliary mutants by the short repressor isoform of Gli3
}

\author{
C Laclef ${ }^{1,2^{*}}$, I Anselme ${ }^{1,2}$, L Besse ${ }^{1,2}$, M Catala ${ }^{1}$, D Baas ${ }^{3,4}$, M Paschaki ${ }^{3,4}$, B Durand ${ }^{3,4}$, S Schneider-Maunoury ${ }^{1,2}$ \\ From Cilia 2014 - Second International Conference \\ Paris, France. 18-21 November 2014
}

Agenesis of the Corpus callosum (AgCC) is a frequent brain disorder found in over 50 human congenital syndromes including ciliopathies. Here, we report a severe AgCC in Ftm/Rpgrip1l knock-out mice, which provide a valuable model for Meckel-Grüber syndrome. Ftm encodes a protein of the ciliary transition zone, which is essential for ciliogenesis in some, but not all cell types in mice, including neuroepithelial cells in the developing forebrain.

We show that AgCC in $\mathrm{Ftm}^{-/}$fetuses results from a mislocalization of guidepost cells in the dorsomedial telencephalon and not from a reduction of callosal neurons in the cortex. This abnormal distribution of the guideposts primarily results from patterning defects in the medial telencephalon, which relies on Gli3 processing defects. These patterning defects, mispositioning of dorsomedial guideposts and AgCC can all be rescued by reintroducing Gli3R in $\mathrm{Ftm}^{-1-}$ embryos, provided by the Gli3D699 allele, which produces only the short repressor isoform of Gli3. This rescue of $\mathrm{AgCC}$ of $\mathrm{Ftm}^{-/-}$mutants by one allele of Gli3D699 confirms and completes our knowledge on the pre-eminent role of Gli3 in CC formation.

Furthermore, Gli3D699 also rescue AgCC in $\mathrm{Rfx}^{-1-}$ mutant, another ciliary mutant deficient for a transcription factor controlling several ciliary genes. Rescuing the $\mathrm{CC}$ formation in two independent ciliary mutants by a single molecule, namely Gli3R, highlight the crucial role of primary cilia in maintaining the proper level of Gli3R required for $\mathrm{CC}$ morphogenesis. These data demonstrate that Gli3 processing is the major outcome of primary cilia function in $\mathrm{CC}$ formation.

\section{Authors' details}

'Sorbonne Université, UPMC Univ. Paris 6, UMR7622, F-75005 Paris, France. ${ }^{2}$ CNRS, INSB, UMR7622, F-75005 Paris, France. 'Université Lyon 1, UMR5534,

'Sorbonne Université, UPMC Univ. Paris 6, UMR7622, F-75005 Paris, France Full list of author information is available at the end of the article
F-69622 Villeurbanne, France. ${ }^{4}$ CNRS, CGPMC-UMR5534, UMR5534, F-69622 Villeurbanne, France.

Published: 13 July 2015

doi:10.1186/2046-2530-4-S1-P36

Cite this article as: Laclef et al:: Rescue of corpus callosum agenesis in two ciliary mutants by the short repressor isoform of Gli3. Cilia 2015 4(Suppl 1):P36.
Submit your next manuscript to BioMed Central and take full advantage of:

- Convenient online submission

- Thorough peer review

- No space constraints or color figure charges

- Immediate publication on acceptance

- Inclusion in PubMed, CAS, Scopus and Google Scholar

- Research which is freely available for redistribution
() Biomed Central
() Biomed Central

(c) 2015 Laclef et al. This is an Open Access article distributed under the terms of the Creative Commons Attribution License (http:// (c) 2015 Laclef et al. This is an Open Access article distributed under the terms of the Creative Commons Attribution License (http://
creativecommons.org/licenses/by/4.0), which permits unrestricted use, distribution, and reproduction in any medium, provided the original work is properly cited. The Creative Commons Public Domain Dedication waiver (http://creativecommons.org/publicdomain/ zero/1.0/) applies to the data made available in this article, unless otherwise stated. 